Research.

\title{
Influence of organizational culture, supervision and environmental work towards discipline of Cicau village employees
}

\author{
Rahmat Hidayat \\ Pelta Bangsa University, Bekasi, Indonesia \\ ramatadzki@ymail.com \\ Dadang Heri Kusumah \\ Pelta Bangsa University, Bekasi, Indonesia \\ dadangherikusumah3@gmail.com
}

Received: August 12, 2019; Accepted: November 7, 2019; Published: December 31, 2019.

To cite this article: Hidayat, Rahmat, Dadang Heri Kusumah. (2019). Influence of Organizational Culture, Supervision and Environmental Work Towards Discipline of Cicau Village Employees. The Accounting Journal of Binaniaga. 4 (2): 61-72. doi: 10.33062/ajb.v4i2.342

Abstract. Each organization is required to be able to optimize human resources and human resources who are able to work hard and have high productivity. Achieving high productivity is not an easy thing to do. An important factor for achieving high productivity is the implementation of work discipline from its employees. In order for the company's operational activities to run well, supervision is needed. The purpose of supervision is for employees to be careful in their work. Supervision is very important, because with the supervision, the employee is serious in working. In addition, the work environment plays an important role in humans who play a role in achieving success in human endeavor or work. The main basis for implementing the work environment is knowledge and attention to human behavior as a determining factor for organizational success. This study aims to determine the effect of organizational culture, supervision and work environment on village employee work discipline. This type of research is quantitative. For data collection includes observations, questionnaires, and literature studies. The analytical methods used are validity test, reliability test, classic assumption test, multiple linear analysis and hypothesis testing.

Keywords: Organizational culture, Supervision, Work environment, and work discipline.

\section{Introduction}

In the current era of globalization, competition between individuals and groups is increasingly high. To face competition to the fullest, human resources must be further improved. Good human resources are very important for achieving a goal. However, to achieve maximum human resources is not easy, it requires hard work and strong commitment to obtain the results to be achieved. The existence of an organization is very much needed as a forum that can gather or facilitate humans in socializing and working together.

Human resources are a part that has an important role in an organization that is a planner in every organization's activities. Some human resource management activities such as supervision, employee motivation, assessment, discipline and others. Human resources are assets that must be constantly considered to obtain human resources that 
have good performance, so they can develop organizations in various community demands and the times. To create reliable human resources requires good and optimal management, so that the achievement of company goals that are influenced by the performance of the company's own employees can be maximized (Indra et al., 2016)

In an effort to support the achievement of organizational goals, quality and professional human resources are also needed. Every organization is demanded to be able to optimize its human and human resources who are able to work hard and have high discipline. As in the study of Frida and Christina (2018) that organizational culture has a significant influence on the work discipline of employees of PT Inti Karya Persada Tehnik.

Achieving high productivity is not an easy thing to do. An important factor for achieving high productivity is the implementation of work discipline from its employees, because it is one of the factors that determine the success and progress in achieving goals (Damayanti and Fakhri, 2014). The quality of work discipline reflects the level of employee responsibility for the tasks assigned to him, therefore good work discipline is expected to increase in employee productivity and performance (Frida, Christina 2018).

Improving work discipline generally aims to provide feedback to employees in an effort to improve the appearance of their work and efforts to increase organizational productivity, and specifically carried out in connection with various policies towards employees such as for promotional purposes, salary increases, education and training. So the assessment for work discipline can be the basis for assessing the extent to which HR activities are carried out well.

In order for the company's operational activities to run well, supervision is needed. The purpose of supervision is for employees to be careful in their work. Supervision is very important, because with the supervision, the employee is serious in working. This is supported by Samura's research (2017) that supervision has a significant influence on employee work discipline at the Office of the Environmental Agency of Rokan Hulu Regency. Supervision is not only done at the end of the management process, but at every level of the management process (Kamal, 2015).

Organizations need to pay attention to various factors that can affect the work environment of employees, in this case the role of the organization is needed in improving and creating a conducive work environment to encourage the creation of professional attitudes and actions in completing work in accordance with their respective fields and responsibilities. As research by Herawati and Ranteallo (2019) that the work environment has a positive and significant effect on employee work discipline at PT RPJ.

The work environment in everyday life has a variety of understanding both related to individual behavior and organizational behavior. The work environment is an important element in humans who play a role in realizing success in human endeavor or work. The main basis for implementing the work environment is knowledge and attention to human behavior as a determining factor for organizational success.

\section{Literature Review}

\section{Work Discipline}

Discipline shows a condition or attitude of respect that exists in employees against the rules and regulations of the company. Thus if the rules or regulations in the company are ignored, or often violated, then the employee has bad discipline. We recommend that if employees are subject to company provisions, illustrate the existence of good discipline conditions, while according to Andriani (2010: 973) in Samura (2017) work discipline can be defined as an effort to move employees to follow and meet work guidelines, the rules that has been outlined by companies that have the basic purpose of driving selfdiscipline. 
Indicators of Work Discipline according to Hasibuan (2002) in Indra et al., (2016) are as follows:

1. Purpose and Ability

The purpose and ability to influence the level of employee discipline. The goals to be achieved must be clear and set ideally and quite challenging for the ability of employees.

2. Leadership

Leadership is very instrumental in determining employee discipline, because leaders are made role models and role models by their subordinates.

3. Justice

Justice contributes to the realization of employee discipline, because ego and human nature always feel important and ask to be treated the same as other humans.

\section{Attached Supervision}

Inherent supervision effectively stimulates company employee discipline. Employees feel they are getting attention, guidance, guidance, direction and direction from their superiors.

5. Assertiveness

The firmness of the leadership in taking action will affect the discipline of the company's employees.

\section{Sanctions}

Sanctions play an important role in maintaining employee discipline.

\section{Organizational culture}

An organizational culture does not automatically form, however, all through a long process that is related to various interactions that occur in the organizational environment. According to Robbins, (2014: 289) argues that "Organizational culture is a shared perception shared by members of the organization". Organizational culture is a way of thinking shared by all members of the organization and new members learn and accept part of the culture in order to be accepted as part of the organization.

According to Luthans (2011: 137) in Damayanti and Fakhri (2014) stated that organizational culture is a basic pattern of thought taught to new personnel as a way to feel, think and act correctly from day-to-day. According to Robbins and Judge (2014) in Frida and Christina (2018) "stated that organizational culture is something that is related to a system within an organization or company that is held and interpreted together by all members or employees so that it can differentiate an organization with other organizations ".

The expression states that organizational culture is something related to a system in an organization or company that is held and interpreted together by all members or employees so that it can distinguish an organization from other organizations. According to Umam (2010) in Damayanti and Fakhri (2014) an organization is a group of people who have the same beliefs, values and assumptions that will be the basis for everyone in the organization to interpret every action either they take or the actions of others.

\section{Organizational Culture Indicator}

According to Robbins and Judge (2014: 512) cited in Frida and Christina (2018) there are 7 main indicators and are the core of organizational culture, namely:

Rahmat Hidayat and Dadang Heri Kusumah. Influence of Organizational Culture, Supervision and Environmental Work Towards Discipline of Cicau Village Employees 
1. Innovation and risk taking

In carrying out the tasks, the organization is more oriented to the pattern of the approach of "using existing traditions" and uses proven methods and gives flexibility to its members to implement new ways through experimentation. Innovation and risk taking are actions in innovation and dare to take risks in the innovation process.

2. Orientation results

Benefit orientation means that management is oriented / focused on results / benefits and not only on the process of getting those results.

3. Team orientation

Team orientation is the act of prioritizing work activities in organizations based on teams, not individuals.

4. Stability

Situations where organizational activities are more focused on maintaining the status quo as opposed to development.

\section{Work Supervision}

Supervision is basically an activity comparing existing conditions with conditions that should occur. If it turns out to be found a deviation or obstacle immediate correction action is taken. According to Handoko (2003) in Kamal (2015) "Supervision implies maintaining stability and equilibrium". To achieve balance, however, managers must always do what they do or change the standards used now to measure implementation. Monitoring techniques and methods should be used simultaneously, not alone. According to Hasibuan (2014: 241) argues that supervision is the process of regulating various factors within a company, so that the implementation is in accordance with the provisions in the plan.

\section{Supervision Indicator} are:

Supervision indicators according to Pasaribu (2011: 34-35) cited in Samura (2017)

1. Monitoring

Namely checking directly about the person or how the incident occurred and where the subordinate was on duty.

2. Inspection

Namely supervision carried out through observation, recording, investigation and analysis carefully and systematically and through an assessment of everything that has to do with work.

3. Guidance and direction

All activities undertaken by the leadership in providing advice on the implementation of tasks.

4. Discipline

All efforts undertaken by the leadership of subordinates in the context of providing sanctions for those who violate the applicable provisions.

\section{Work environment}

According to Sutrisno (2010) in Fatoni (2018) "the work environment is the overall work facilities and infrastructure that are around the workplace that can affect the implementation of work. The work environment includes the place of work, facilities and

Rahmat Hidayat and Dadang Heri Kusumah. Influence of Organizational Culture, Supervision and Environmental Work Towards Discipline of Cicau Village Employees 
work aids, cleanliness, lighting, tranquility, as well as work relationships between people who are in the place ". According to Sunyoto (2012) in Herawati and Asrah (2019) stated that the work environment is everything that exists around the workers and that can affect him in carrying out the tasks assigned.

According to Sutoyo (2016) in Frida and Christina (2018) suggested that the work environment is a condition around the workplace both physically and non-physically that has an impact on pleasure, safety and calmness. According to Terry (2006) in Samura (2017) the work environment can be interpreted as a strength that influences, both directly and indirectly, on the performance of an organization or company.

\section{Work Environment Indicator}

According to Suwatno (2011) cited in Herawati and Ranteallo (2019) Work environment indicators are divided into two types, namely:

1. Physical work environment

The physical work environment is all physical forms that are around the workplace and can affect employees. Siagian (2014: 59) states that the dimensions of the physical work environment consists of several types, namely:

a. Workplace building

Workplace buildings in addition to dancing to be seen are also built with work safety considerations, so that employees are comfortable in completing their work.

b. Adequate working equipment

Adequate work equipment is needed by employees because it will support employees in completing their tasks.

c. Amenities

Company facilities are needed by employees as supporters in completing their work.

2. Non-physical work environment

Non-physical work environment is the creation of a harmonious working relationship between employees and superiors. Siagian (2014: 61) states that the dimensions of the non-physical work environment consists of several types, namely:

a. Peer-level relationships

Relationship indicators with coworkers are relationships with coworkers that are harmonious and without mutual intrigue between co-workers.

b. Relationship between employer and employee

Relationship between superiors and subordinates must be maintained properly and must respect each other between superiors and subordinates, with mutual respect it will lead to respect among each individual.

c. Collaboration between employees

Collaboration between employees must be maintained well, because it will affect the work they do. If cooperation between employees can be established properly then employees can complete their work effectively and efficiently.

Rahmat Hidayat and Dadang Heri Kusumah. Influence of Organizational Culture, Supervision and Environmental Work Towards Discipline of Cicau Village Employees 


\section{Hypothesis}

The hypotheses in this scientific work, with the theme of the influence of organizational culture, supervision and work environment on the work discipline of Cicau Village employees are determined as follows:

The first hypothesis: allegedly organizational culture influences work discipline, which in this hypothesis is supported by:

1. Fatchuriza Frida, Lenny Christina Nawangsari, in a journal entitled The Influence of Work Motivation, Organizational Culture, and Work Environment on the Work Discipline of Employees at PT Inti Karya Persada Tehnik, Volume 8, Issue 12, ISSN 2250-3153, 2018

2. Dwitya Damayanti and Mahendra Fakhri, in a journal entitled the influence of organizational culture on the work discipline of employees of PT Angkasa Pura 11 (Persero) Soekarno-Hatta International Airport Main Branch Office Personnel \& General Affairs Unit, volume 1, No. 3, 2014, resulted in the conclusion that organizational culture has a positive and significant influence on the work discipline of PT Angkasa Pura 11 (Persero) KCU Soekarno-Hatta International Airport, Personnel \& General Affairs Unit.

The second hypothesis: alleged supervision has an influence on employee work discipline, this hypothesis is supported by:

1. Ibnu Sina Samura, in a journal entitled the effect of supervision and work environment on the work discipline of Rokan Hulu Regency Environmental Agency Officers, volume 4, No 1, 438447, 2017, concludes that supervision has a significant effect on the work discipline of Employees of the Environmental Agency Office Long live Rokan Hulu Regency.

2. M. Basri Kamal, in a journal entitled the effect of leadership and supervision on the work discipline of the employees of PT. Perkebunan Nusantara 111 (PERSERO), volume 15 , NO. 1, 2015, resulting in the conclusion that leadership has a significant effect on work discipline, supervision has a significant effect on work discipline and the most dominant variable influencing work discipline is the supervision variable.

Third Hypothesis: alleged work discipline is influenced by the work environment, which in this hypothesis is supported by:

1. Niken Herawati and Asrah Tandirerung Ranteallo, in the journal Influence of Work Environment on Employee Work Discipline at PT RPJ, volume 4, No 2, 2019, results that the work environment has a positive and significant effect on employee work discipline at PT RPJ.

2. Indra et al., In a journal entitled Effect of democratic leadership style and work environment on employee performance and discipline volume 2, No 2, 2016, produced the conclusion that the work environment has a positive influence on work discipline.

\section{Research Method}

\section{Types of research}

This study uses quantitative methods, methods that emphasize aspects of measurement objectively of social phenomena. (Sugiyono, 2014) it is based on the title studied, namely "The Effect of Organizational Culture, Supervision and Work Environment on the Discipline of the Work of Cicau Village Employees". The writer wants to know whether there is an influence between organizational culture, supervision and work environment on employee work discipline. 


\section{Research design}

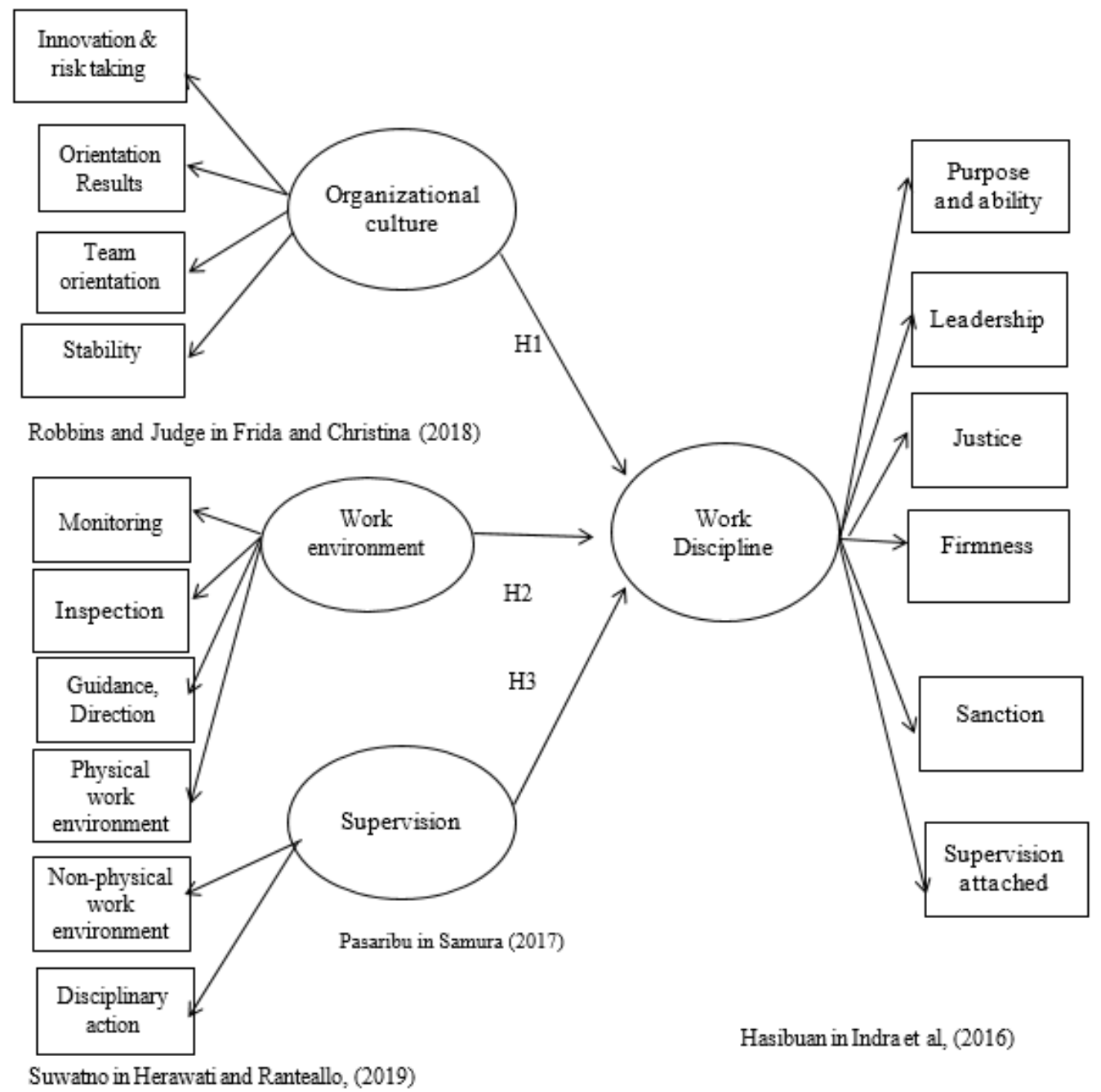

Figure.

Research design

Information:

$\mathrm{H} 1=\mathrm{X} 1 \mathrm{Y}$ : Fatchuriza Frida, Lenny Christina, International Journal of Scientific and Research Publications, Volume 8, Issue 12, December 2018. Dwitya Damayanti and Mahendra Fakhri, Journal of Business Administration volume 1, No. 3, 2014 (Robbins and judge, 2014 in Frida and Christina, 2018)

$\mathrm{H} 2$ = X2 Y : Ibn Sina Samura, Student Online journal, volume 4, No. 1, 438447, 2017. M. Basri Kamal, Journal of Management and Business volume 15, No. 1, 2015. (Pasaribu, 2011 in Samura, 2017)

$\mathrm{H} 3=\mathrm{X} 3 \mathrm{Y}$ : Niken Herawati and Asrah, Familiar journal Champion Volume 4, No. 2, 2019. Indra et al., Journal of Management, volume 2, No 2, 2016. (Suwatno, 2011 in Herawati and Ranteallo, 2019)

Rahmat Hidayat and Dadang Heri Kusumah. Influence of Organizational Culture, Supervision and Environmental Work Towards Discipline of Cicau Village Employees 


\section{Results and Discussion}

\section{Validity and Reliability Test}

1. Validity test

Validity or validity is showing the extent to which a measuring instrument is able to measure what you want measured. The measuring instrument used in this study is SPSS Version 22, an instrument said to be valid if the significant value is smaller than 0.05 or the variable is declared valid if the value of $r$ count is greater than $r$ table.

2. Normality test

It aims to test whether in the regression model, the residual variable has a normal distribution or not. A good regression model is one that has a normally distributed residual value.

The normality test used in this study is the one sample Kolmogorof-Smirnov test, where the residual value is normally distributed if the sig value $>0.05$. From the normality test it can be concluded that the significance value (Asymp.Sig 2-tailed) $=$ $0,200>0.05$ then the residual value is stated as normally distributed.

3. Multiple Linear Regression Analysis Test

Multiple linear regression analysis is used to determine the effect or linear relationship between two or more independent variables with one dependent variable.

Table.

The results of multiple linear regression analysis test

\begin{tabular}{|c|c|c|c|c|c|c|}
\hline \multicolumn{7}{|c|}{ Coefficients $^{\mathrm{a}}$} \\
\hline \multirow{2}{*}{\multicolumn{2}{|c|}{ Model }} & \multicolumn{2}{|c|}{ Unstandardized Coefficients } & \multirow{2}{*}{$\begin{array}{c}\text { Standardized } \\
\text { Coefficients } \\
\text { Beta } \\
\end{array}$} & \multirow[b]{2}{*}{$\mathrm{T}$} & \multirow[b]{2}{*}{ Sig. } \\
\hline & & B & Std. Error & & & \\
\hline \multirow[t]{4}{*}{1} & (Constant) & 17.914 & 5.283 & & 3.391 & .001 \\
\hline & Organizational culture & .372 & .121 & 290 & 3.063 & .003 \\
\hline & Inspection & -.079 & .124 & -.052 & -.640 & .524 \\
\hline & Work environment & .893 & .157 & .532 & 5.682 & .000 \\
\hline
\end{tabular}

The regression equation can be explained as follows:

a. The constant value is 17,914 meaning that if the organizational culture (x1), supervision ( $\mathrm{x} 2$ ) and work environment (x3) value is 0 , then the value of work discipline is $17.914 \%$.

b. The regression coefficient of the organizational culture variable is 0.372 meaning that if the culture of the organization has increased by one unit, the work discipline will increase by 0.372 units assuming the other independent variables are of fixed value.

c. The regression coefficient of the supervision variable is -0.079 meaning that if supervision has decreased by one unit, the work discipline will decrease by -0.079 units assuming the other independent variables are of fixed value.

d. The regression coefficient of the work environment variable is 0.893 meaning that if the work environment has increased by one unit, then the work discipline will experience an increase of 0.893 units assuming the other independent variables are of fixed value.

Rahmat Hidayat and Dadang Heri Kusumah. Influence of Organizational Culture, Supervision and Environmental Work Towards Discipline of Cicau Village Employees 
The Accounting Journal of BINANIAGA Vol. 04, No. 02, December 2019

p-ISSN: $2527-4309$, e-ISSN: $2580-1481$

$5^{\text {th }}$ Accreditation Rating: January 14, 2019 - January 13, 2024

\section{Hypothesis testing}

The t test (partial regression coefficient) was used to find out the significant effect between the independent variables on the dependent variable with a significant $<0.05$ and $t$ arithmetic $>t$ table.

Table.

T-Test Results

\begin{tabular}{|c|c|c|c|c|c|c|}
\hline \multicolumn{7}{|c|}{ Coefficients $^{a}$} \\
\hline & & \multicolumn{2}{|c|}{$\begin{array}{l}\text { Unstandardized } \\
\text { Coefficients }\end{array}$} & \multirow{2}{*}{$\begin{array}{l}\text { Standardized } \\
\text { Coefficients } \\
\text { Beta }\end{array}$} & \multirow[b]{2}{*}{$\mathrm{T}$} & \multirow[b]{2}{*}{ Sig. } \\
\hline \multicolumn{2}{|c|}{ Model } & $B$ & Std. Error & & & \\
\hline \multirow[t]{4}{*}{1} & (Constant) & 17.914 & 5.283 & & 3.391 & .001 \\
\hline & Drganizational culture & .372 & .121 & .290 & 3.063 & .003 \\
\hline & Inspection & -.079 & .124 & -.052 & -.640 & .524 \\
\hline & Work environment & .893 & 157 & .532 & 5.682 & .000 \\
\hline
\end{tabular}

Based on the results of the output in the t test for organizational culture variables (X1) obtained t value of 3.063 while the $t$ table at $5 \%$ distribution is 1.992 . Because $t$ arithmetic (3.063)> t table (1.992) and the significance value is smaller than $0.05(0.003$ $<0.05)$ then $\mathrm{H} 1$ is accepted, meaning that organizational culture partially has a significant effect on work discipline.

$\mathrm{T}$ test results for the monitoring variable (X2) obtained $t$ value of -0.640 while the value of the $5 \%$ distribution table obtained t table of 1.992 . Because $t$ arithmetic $(-0.640)$ $<\mathrm{t}$ table (1.992) and a significant value of $0.524>0.05$ then $\mathrm{H} 2$ is rejected, meaning that supervision has no partial effect on work discipline.

$T$ test results for the monitoring variable $(X 3)$ obtained $t$ value of 5.682 while the value of the $5 \%$ distribution table obtained $t$ table of 1.992 . Because $t$ arithmetic (5.682) $>t$ table (1.992) and a significant value of $0.000<0.05, \mathrm{H} 3$ is accepted, meaning that the work environment has a partial effect on work discipline.

\section{Conclusions and Recommendations}

\section{Conclusion}

Based on research on the influence of organizational culture, supervision and work environment on the work discipline of Cicau Village employees in 2019 to 79 village employee respondents, the authors conclude from this study:

1. Organizational culture has a significant positive effect (0.372) on the work discipline of Cicau Village employees and the value of $t$ arithmetic (3.063)> $t$ table (1.992) and the significance value is less than $0.05(0.003<0.05)$.

2. Oversight has no positive and significant effect $(-0.079)$ on the work discipline of Cicau Village employees and the $t$-value is -0.640 while the value in the $5 \%$ distribution table is obtained $t$ table of 1.992 . Because $t$ arithmetic $(-0.640)<t$ table (1.992) and a significant value of $0.524>0.05$.

3. The work environment has a significant positive effect $(0.893)$ on the work discipline of Cicau Village employees and the t value of 5.682 while the value in the 
$5 \%$ distribution table is obtained $t$ table of 1.992. Because $t$ arithmetic (5.682) $>t$ table (1.992) and a significant value of $0,000<0.05$.

4. Organizational culture, supervision and work environment influenced the work discipline of Cicau Village employees by $52.3 \%$.

\section{Suggestion}

Based on the above conclusions, in this study suggestions that need to be considered for the Cicau Village Management Center in Cikarang and for researchers conducting future research are as follows:

1. Village Government is advised to continue to pay attention to the current village government policies in accordance with the principles for all village employees.

2. Village staff are expected to be able to carry out all their duties and responsibilities properly.

3. The results of this study are expected to be an additional reference for further research, the need for further research on organizational culture, supervision and work environment of the work discipline of Cicau Village employees so as to obtain a broader picture.

\section{References}

Biovani, L and Ari, P. (2018). Pengaruh Kepemimpinan dan Budaya Organisasi Terhadap Disiplin Kerja, terbit di journal of Social and Politic.

Bintarti, S. (2015). Metodologi Penelitian Ekonomi Manajemen. Mitra Wacana Media, Jakarta.

Damayanti, D and Mahendra. (2014). Pengaruh Budaya Organisasi Terhadap Disiplin Kerja Karyawan PT Angkasa Pura 11 (persero) Kantor Cabang Utama Bandara Internasional Soekarno- Hatta Unit Personnel \& General Affairs, terbit di jurnal Administrasi Bisnis, 1(3).

Fatoni, A. (2018). Pengaruh Sanksi, Motivasi Dan Lingkungan Kerja Terhadap Disiplin Kerja Pegawai UPT Pengujian Kendaraan Bermotor Kota Malang, terbit di jurnal Riset Manajemen, 7(2).

Frida, F and Lenny. (2018). The Influence of Work Motivation, Organizational Culture, and Work Environment on the work Discipline of Employees PT Inti Karya Persada Tehnik, terbit di jurnal International Journal of Scientific and Research Publications, 8(12).

Hasibuan, M.S.P. (2014). Manajemen Sumber Daya Manusia. Jakarta : Bumi Aksara.

Herawati, N and Asrah. (2019). Analisis Pengaruh Lingkungan Kerja Terhadap Disiplin Kerja pada PT RPJ, terbit di jurnal Akrab Juara, 4(2).

Indra et al. (2016). Pengaruh Gaya Kepemimpinan Demokratis dan Lingkungan Kerja Terhadap Kinerja dan Kedisiplinan karyawan, terbit di jurnal unpand.ac.id, 2(2).

Kamal, M.B. (2015). Pengaruh Kepemimipinan Dan Pengawasan Terhadap Disiplin Kerja Karyawan PT. Perkebunan Nusantara 111 (PERSERO), terbit di jurnal Ilmiah Manajemen dan Bisnis, 15(1).

Robbins and Judge. (2014). Organizational Behavior. New Jersey: Pearson Education, Inc.

Rahmat Hidayat and Dadang Heri Kusumah. Influence of Organizational Culture, Supervision and Environmental Work Towards Discipline of Cicau Village Employees 
Saragih, 2012. Pengaruh Lingkungan Kerja Terhadap Disiplin Kerja Karyawan Pada PT. Kawalram Indonesia, 4(3).

Sedarmayanti. (2013). Sumber Daya Manusia Dan Produktivitas Kerja. Bandung: Mandar Maju.

Sina, I. (2017). Pengaruh Pengawasan Dan Lingkungan Kerja Terhadap Disiplin Kerja Pegawai Kantor Badan Lingkungan Hidup Kabupaten Rokan Hulu, terbit di jurnal online mahasiswa, 4(1).

Situmorang and Juhir. (2008). Aspek Hukum Pengawasan Melekat Dalam Lingkungan Aparatur Pemerintahan PT Rineka Cipta. Jakarta.

Sulma. (2016). Pengaruh Pengawasan Terhadap Disiplin Kerja Pegawai Negeri Sipil di Sekretariat Daerah Kabupaten Kepulauan Sula, terbit di jurnal Administrasi Publik, 1(36). 
The Accounting Journal of BINANIAGA Vol. 04, No. 02, December 2019

p-ISSN: $2527-4309$, e-ISSN: $2580-1481$

$5^{\text {th }}$ Accreditation Rating: January 14, 2019 - January 13, 2024

This page intentionally be emptied.

Rahmat Hidayat and Dadang Heri Kusumah. Influence of Organizational Culture, Supervision and Environmental Work Towards Discipline of Cicau Village Employees 